\title{
Charles B. Bourne
}

\author{
(1921-2012)
}

Tt was with great regret that the Board of Editors learned of the death of the Canadian Yearbook of International Law's founding editor-in-chief, Charles Bourne.

Charles Bourne had a long and distinguished career as an international lawyer. A graduate of the University of Toronto, Cambridge University, and the Harvard Law School, he taught initially at the University of Saskatchewan and then for many years at the University of British Columbia, where he was at the forefront of the international law program for over thirty years. Many of his former students went on to have distinguished careers in the field of international law, including several legal advisers to the Canadian Department of External (later Foreign) Affairs. His intellectual rigour, his clarity of thought, his attention to detail, and his high professional standards were all passed on, and they stayed with those taught by him or indeed anyone who came into contact with him.

As a scholar, Charles was renowned for his work in the field of international water resources law. A long-time chair of the International Law Association Committee on Water Resources Law, Charles was one of the authors of the Helsinki Rules, which set the standard for the field and remain a hallmark today. As Academicin-Residence in the Department of External Affairs in the early 1970s, Charles worked on the Great Lakes Water Quality Agreement, and he was an authority on the Columbia River Treaty as well.

In addition to his numerous articles on international law, Charles' great scholarly contribution was as the founding editor-in-chief of this Yearbook. Starting with little and working with a group of other Canadian scholars who were committed to the project, Charles built the Yearbook over the thirty years he served as editor-in-chief to the place in international legal scholarship it holds today. Charles had high standards - articles had to meet those standards in order to 
be accepted and then they were subjected to a rigorous, if at times idiosyncratic, editorial process. The objective was to publish work of high quality and to provide a forum for the work of Canadian scholars and Canadian practice in international law. The result, as the volumes of the past and this volume show, speaks for itself. The Yearbook bears the indelible imprint of Charles Bourne, the scholar, and of Charles Bourne, the man.

A full account of the career and contribution of Charles Bourne is found in the article in volume 34 of the Canadian Yearbook of International Law by Ronald St. J. Macdonald, "Charles B. Bourne: Scholar, Teacher, and Editor, Innovator in the Development of the International Law of Water Resources." 1 The opening line of this article provides a fitting tribute: "Charles B. Bourne is a role model for anyone pursuing a career in public international law in Canada."2

On a personal note, Charles Bourne was a man I admired, a mentor, a scholar to emulate, and one whose standards were ideals to live up to - he was a true role model. He fostered my career as an international lawyer and then paid me the honour of inviting me to succeed him as editor-in-chief of this yearbook. Charles Bourne's passing saddens, but his contribution was immense and his legacy endures.

Donald M. McRae Editor-in-Chief (I993-20IO)

1 Ronald St J Macdonald, "Charles B. Bourne: Scholar, Teacher, and Editor, Innovator in the Development of the International Law of Water Resources" (1996) 34 Can YB Int'l Law 3.

2 Ibid at 3 . 